\title{
Faktor Tarikan Dakwah Mohd Fadli Yusof dalam Pengislaman Masyarakat Non-Muslim di Pedalaman Pensiangan, Sabah
}

\author{
Abd Hadi Borham \\ Universiti Pendidikan Sultan Idris, abdhadi.borhan@fsk.upsi.edu.my \\ Fakhrul Adabi Abdul Kadir \\ Universiti Malaya, fakhruladabi@um.edu.my
}

\begin{abstract}
Abstrak
Makalah ini membincangkan mengenai faktor-faktor tarikan dalam dakwah. Ia memfokuskan kepada faktor-faktor tarikan dalam dakwah Mohd Fadli Yusof terhadap masyarakat non-muslim di Sabah. Beliau merupakan salah seorang pendakwah bebas yang telah menjalankan usaha dakwah kepada masyarakat non-muslim di bahagian pedalaman Sabah sejak tahun 2011. Dalam tempoh dua tahun, beliau telah berjaya mengislamkan seramai 269 orang non-muslim dan membina sebuah masjid di kawasan pedalaman Pensiangan, Sabah. Bagi melihat perkara tersebut, kajian ini dilakukanuntuk mengenal pasti faktor-faktor tarikan dakwah Mohd Fadli Yusof dalam pengislaman masyarakat non-muslim di pedalaman Pensiangan. Kajian lapangan ini menggunakan kaedah pemerhatian ikut serta dan temu bual informan di Kampung Padang, mukim Sepulut pedalaman Pensiangan. Hasil kajian mendapati lima faktor tarikan dakwah Mohd Fadli Yusof iaitu faktor tarikan qudwah, quwwah, kelainan, berulang-ulang dan keprihatinan.
\end{abstract}

Kata kunci: dakwah, pengislaman, Mohd Fadli Yusof, non-muslim, masyarakat pedalaman Sabah

\section{Attraction Factors of Mohd Fadli Yusof's Da'wah in the Islamization of Non-Muslim Communities in Rural of Pensiangan, Sabah}

\begin{abstract}
This article discuss on attractions of da'wah in Islamic da'wah. It focuses on Mohd Fadli Yusof da'wah attractions in the Islamization of non-Muslim communities in rural of Pensiangan, Sabah. He is independence of $d \bar{a} ' \hat{\imath}$, who was active in da'wah non-muslim since 2011. In the short times, he was successful convert 269 non-muslim to Islam and built a mosque in rural of Pensiangan, Sabah. This study aim to identify an attractions factors on Mohd Fadli Yusof da'wah in rural of Pensiangan, Sabah. The study used qualitative research with participant observation and interview methods. Data was obtained in Kampung Padang, Sepulut, Pensiangan Sabah. The finding shows that five
\end{abstract}


attraction factors on da'wah Mohd Fadli Yusof in rural of Pensiangan, Sabah. These factors are qudwah attraction, quwwah attraction, different attraction, repetitive attraction and concern attraction.

Keywords: da'wah, Islamization, Mohd Fadli Yusof, non-muslim, Sabah rural community

\section{Pendahuluan}

Tarikan dakwah adalah sesuatu yang menarik di antara pendakwah dan sasaran dakwah. ${ }^{1}$ Ia dilihat dengan bagaimana pendakwah mampu mempengaruhi sasaran dakwah dan sasaran dakwah pula tertarik dengan dakwah yang disampaikan. Di atas faktor tersebut, terdapat banyak penulisan yang menyentuh tarikan dakwah secara langsung dan tidak langsung melalui faktor akhlak yang menjadi qudwah kepada orang lain. Ia merupakan salah satu ciri yang menjadi tarikan kepada non-muslim dan mendorong mereka memeluk Islam. ${ }^{2}$ Walau bagaimanapun, kegagalan orang Islam hari ini menjadi contoh dalam kehidupan agamatelah memberikan gambaran kurang menarik terhadap agama Islam dan penganutnya. ${ }^{3}$ Di samping itu, propaganda media yang bertali arus memberikan gambaran negatif tentang Islam menjadikan nonmuslim bersikap prejudis dan menjauhkan diri daripada dakwah. ${ }^{4}$ Tulisan ini melihat tentang faktor tarikan dakwah dan mengenal pasti faktor-faktor tersebut dalam dakwah Mohd Fadli Yusof di pedalaman, Pensiangan Sabah.

\footnotetext{
${ }^{1}$ H.MAriffin, Psikologi Da'wah, Suatu Pengantar Studi (Jakarta: Penerbit Bulan Bintang, 1977), 15.

2 'Abd al-Karīm Zaydān, Usūl al-Da'wah (Beirut: al-Risalah Publisher, 1998), 470.

${ }^{3}$ Ibrahim Che Noh, "Dakwah kepada Non-Muslim," dalam Dakwah Islamiah Malaysia Masa Kini, ed. Sidi Gazalba dan Zainab Ismail (Bangi: Penerbit Universiti Kebangsaan Malaysia, 1995), 92.

4 Desmond Davidson, "Sabah Christians Meet Today in Bid to Reverse Conversions to Islam," The Malaysian Insider, retrieved on 4 Febuary 2014, http://www.themalaysianinsider.com/malaysia/article/sabah-christians-meettoday-in-bid-to-reverse-conversions-to-islam.
} 


\section{Definisi Tarikan Dakwah}

Dalam Kamus Dewan, tarikan bermaksud perkara yang menarik, daya menarik dan perihal menarik. ${ }^{5}$ Dalam bahasa Inggeris, tarikan disebut 'attraction.' Dalam kamus Oxford Advanced Learner's Dictionary, 'attraction' bermaksud perasaan suka dan menarik. ${ }^{6}$ Dalam kamus Merriam-Webster, 'attraction' bermaksud sesuatu yang menarik perhatian dan mendorong seseorang untuk mendapatkannya atau melawatinya dengan perasaan sukar atau gemar. ${ }^{7}$ Dalam kamus Cambridge Dictionaries Online, 'attraction'bermaksud sesuatu yang menjadikan seseorang itu suka, perasaan suka dan lain-lain. ${ }^{8}$ Dalam bahasa Arab, tarikan disebut jādhibiyyah. ${ }^{9}$ Kamus Al-Mu'jam al- 'Arabiyy al-Asāsiyy memberi pengertian istilah jādhibiyyah dengan maksud daya tarikan pada seseorang, daya tarikan seperti magnet dan daya tarikan graviti bumi yang bersifat kuat. Dalam kamus Mu 'jam alWasìt, jädhibiyyah bermaksud daya tarikan yang kuat pada sesuatu seperti daya tarikan bumi. Ia menunjukkan jädhibiyyah lebih merujuk kepada perkara tarikan sesuatu, bersifat menarik daya tarikan yang kuat.

Daripada maksud-maksud di atas dapat difahami tarikan dalam bahasa Melayu dan bahasa Arab (jädhibiyyah) lebih menunjukkan sifat menarik, daya tarikan yang kuat dan perkaraperkara yang menarik. Manakala dalam bahasa Inggeris (attraction), tarikan dilihat sebagai perkara yang menarik perhatian, tempat menarik yang dilawati, perkara yang disukai dan mendorong seseorang untuk mendapatkannya. Ini menunjukkan tarikan dapat difahami dengan maksud sesuatu perkara yang menarik, mempunyai daya tarikan yang kuat, tempat menarik yang dilawati, perkara yang disukai dan digemari.

\footnotetext{
${ }^{5}$ Kamus Dewan Edisi Keempat (Kuala Lumpur: Dewan Bahasa Dan Pustaka, 2007), 1610, entri "tarikan."

6 A. S. Hornby, Oxford Advanced Learner's Dictionary (United Kingdom: Oxford University Press, 2011), 84, entri "attraction".

7 Merriam-Webster Online, "An Encyclopedia Britannica Company," dicapai pada 25 Jun 2014, http://www.merriam-webster.com/dictionary/attraction, entri "attraction."

8 Cambridge Dictionaries Online, dicapai 25 Jun 2014, http://dicitionary. cambridge.org/dictionary/british/attraction, entri "attraction."

${ }^{9}$ Elias' Modern Dictionary, English-Arabic, (Kaherah: Elias' Modern Publishing House \& Co., 1984) 80, entri "jadhibiyyah.”
} 
Tarikan yang muncul dalam sesuatu perkara akan menarik perhatian orang lain untuk mendapatkannya. Dalam ilmu psikologi, tarikan timbul melalui unsur-unsur atau gejala yang terdapat diri manusia sendiri. Morgan melihat faktor tarikan yang timbul dalam diri manusia disebabkan dua faktor iaitu luaran (external) dan dalaman (internal). Faktor luaran yang mempengaruhi aspek tarikan ialah keamatan dan saiz, berbeza dan sesuatu yang baru, berulang-ulang dan bergerak-gerak. Manakala faktor dalaman dilihat dengan aspek motif atau keperluan biologi manusia, kesediaan terhadap sesuatu dan sifat gemar terhadap sesuatu. ${ }^{10}$ Ia berlaku disebabkan dengan rangsangan melalui deria manusia terhadap sesuatu peristiwa yang mempunyai bentuk fizikal. Chaplin pula menyatakan bahawa rangsangan (stimulus) sebagai apa-apa perubahan yang berlaku dalam bentuk tenaga fizikal yang didaftarkan oleh penerima rangsangan. Manakala deria atau kederiaan merupakan satu peristiwa yang berbentuk psikologikal dan agak kompleks. Deria yang merangsangkan sesuatu tindakan atau menarik perhatian manusia adalah disebabkan menerima rangsangan dari alam melalui deria penglihatan, pendengaran, sentuhan, rasa,menghidu, deria yang optimum dan kederiaan yang luar biasa. ${ }^{11}$

Oleh itu, dapat dinyatakan bahawa tarikan yang muncul dari sesuatu perkara dapat menarik perhatian orang lain untuk memberikan tumpuan kepadanya dan mendapatkannya. Dalam konteks dakwah, tarikan merupakan salah satu perkara yang boleh mempengaruhi golongan sasaran. Misalnya, Allah SWT telah menyatakan tentang ganjaran syurga bagi menggalakkan manusia gemar dan merangsang mereka kepada kebenaran Islam. ${ }^{12}$ Firman Allah:

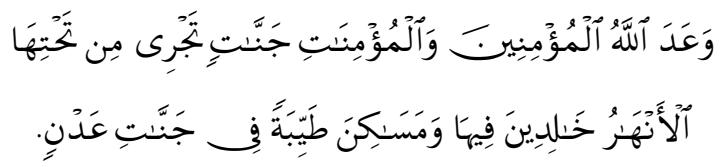

${ }^{10}$ Morgan, King and Robinson, Introduction to Psychology (New York: Mc Graw Hill Book Company, 1979), 315-317.

11 Mahmood Nazar Mohamed, Pengantar Psikologi, Satu Pengenalan Asas Kepada Jiwa dan Tingkahlaku Manusia (Kuala Lumpur: Dewan Bahasa Dan Pustaka, 2005), 59-80.

12 'Abd al-Karīm Zaydān, Usūl al-Da'wah (Beirut: al-Risalah Publisher, 1998), 437. 
Terjemahan: Allah menjanjikan orang-orang yang beriman, lelaki dan perempuan, (akan beroleh) syurga-surga yang mengalir di bawahnya beberapa sungai; mereka kekal di dalamnya dan beroleh tempat-tempat yang baik di dalamnya "Syurga "Adn."

Al-Tawbah 9:72

Dalam ayat di atas, Allah SWT telah menjanjikan syurga 'Adn bagi orang lelaki dan perempuan yang beriman dan melakukan amal salih. Ini menunjukkan balasan syurga yang kekal di dalamnya. Balasan atau janji yang dinyatakan dalam ayat tersebut menarik perhatian di kalangan orang-orang yang beriman untuk melakukan amal salih semasa hidup di dunia dengan bersungguh-sungguh. Dalam masa yang sama, Allah SWT turut mengingatkan manusia agar menjauhi segala perintah laranganNya di dunia dengan balasan kebinasaan, kemurkaandan azab Allah di akhirat. ${ }^{13}$ Ia mengundang balasan Allah dengan bala yang akan menimpa semua manusia tanpa kecuali. ${ }^{14}$

Secara tidak langsung, janji, ganjaran, pahala dan syurga menggambarkan kepada ciri-ciri tarikan kepada dakwah merangsang manusia bersungguh-sungguh melakukan perintah Allah di dunia dan berusaha menjauhkan diri dari kemurkaan-Nya. Ini menunjukkan terdapat ciri-ciri yang boleh menarik perhatian golongan sasaran kepada dakwah. Perkara ini tidak dijelaskan secara khusus, namun ia dibincangkan berdasarkan ciri-ciri yang perlu ada dalam wasilah atau metodologi dakwah. Menurut 'Abd al-Karīm Zaydān, beliau menjelaskan dakwah lisan mestilah menggunakan bahasa yang baik, bersifat lemah lembut dan sesuai dengan keadaan $\operatorname{mad}^{\prime} \bar{u}$. Misalnya, pendakwah menggunakan ciri tersebut dalam khutbah, kelas pengajian, kuliah, perbincangan, menyampaikan amar makruf nahi mungkar dan penulisan. Ini menunjukkan ciri tarikan yang menggambarkan tentang akhlak melalui kelembutan yang boleh mempengaruhi hati manusia yang keras. Dalam konteks amal al-Islamī pula, ia dilakukan dengan menggunakan sistem yang boleh menghapuskan kemungkaran,

\footnotetext{
${ }^{13}$ Ibid.

${ }^{14}$ Muhammad Mutawallī al-Sha'rāwī,Mukhtașar Tafsīr al-Sha 'rāwī (Kaherah: Dār al-Tawfiqiyyah wa al-Turath, 2011), 288.
} 
menunjukkan kemaslahatan dan keindahan Islam. ${ }^{15}$ Keadaan ini menyebabkan faktor agama syumul dan agama rahmat dapat dirasai oleh golongan sasaran secara tidak langsung.

Ahmad Ghalūsh menggariskan enam ciri-ciri dalam wasilah dakwah iaitu mestilah bersifat kemanusiaan, meletakkan suatu perkara yang paling utama daripada perkara-perkara utama yang lain (awläwiyāt) atau memberi keutamaan, mudah dan indah, dan menghubungkan keindahan al-Qur'ān meliputi lafaz, bahasa dan makna untuk memberi kesan kepada hati sasaran. ${ }^{16}$ Ini menunjukkan beliau meletakkan ciri tarikan akhlak melalui hubungan kemanusiaan dan menggunakan wahyu sebagai tarikan berkesan kepada manusia. 'Alī Jarishah pula menyatakan wasilah dalam dakwah mestilah berasaskan al-hikmah, maw'izah alhasanah, mujādalah, contoh terbaik (al-qudwah) dan unsur kekuatan (al-quwwah). ${ }^{17}$ Beliau meletakkan tiga uslub dakwah yang dinyatakan al-Qur'ān dan menambah satu lagi aspek pendekatan dakwah yang boleh mempengaruhi golongan sasaran iaitu kekuatan (al-quwwah).

Selain itu, Mohd Yusof Hussain juga menjelaskan beberapa ciri-ciri yang boleh mempengaruhi golongan sasaran dakwah iaitu menjelaskan berkaitan apa yang dikenali tentang agama Islam, menjadikan Islam mudah untuk dipraktik, memujuk, menggunakan rasional (tafakar), memberi ganjaran (reward), pendekatan tarhīb dan qudwah hasanah. ${ }^{18}$ Ini menunjukkan beliau meletakkan aspek mudah, lembut, logik, memberi hadiah, memberi kegembiraan dan menonjolkan kebimbingan sebagai ciriciri dalam tarikan dakwah. Manakala Ab Aziz Mohd Zin menyatakan ciri-ciri tarikan dakwah dihubungkan dengan aspek psikologi manusia. Antaranya ialah persembahan yang cantik, mengemukakan sesuatu yang baru, bersimpati dengan masalah sasaran, mengemukakan isu tepat pada waktunya, menonjolkan

15 'Abd al-Karīm Zaydān, Usūl al-Da'wah (Beirut: al-Risalah Publisher, 1998), 485.

16 Ahmad Ahmad Ghalūsh, Al-Da'wah al-Islāmiyyah Ușūlihā wa Wasā'iluhā (Kaherah: Dār al-Kitāb al-Mișr, 1978), 276-285.

17 'Alī Jarishah, Manāhij al-Da 'wah wa Asālibihā (Mansurah: Dār al-Wafā' li alTibā'ah wa al-Nashr wa al-Tawzi', 1986), 139.

18 Mohd Yusof Hussain, "Method in Contemporary Islamic Da'wah," dalam Readings in Islamic Da'wah, ed. Mohd. Yusof Hussain (Kuala Lumpur: International Islamic University Malaysia (IIUM) Press, 2009), 64-66. 
unsur-unsur yang perlu, berdasarkan psikologi dan mempunyai penguasaan ilmu yang luas. ${ }^{19}$ Aspek tersebut menunjukkan ciriciri yang boleh menarik perhatian melalui pancaindera, fizikal dan mental manusia kepada dakwah.

Oleh itu, dapat difahami ciri-ciri faktor tarikan dalam dakwah mestilah menggunakan bahasa yang baik dan mudah, memahami keadaan sasaran, akhlak yang mulia, menjadi contoh ikutan, melakukan apa yang disampaikan, bersifat kemanusiaan, melihat keutamaan yang dikehendaki mad' $\bar{u}$, mudah, menonjolkan keindahan Islam, menggunakan mukjizat al-Qur'an, berasaskan alhikmah, maw'izah al-hasanah, mujādalah, al-qudwah, al-quwwah, menggunakan logik, memberi ganjaran, targhīb dan tarhīb, sesuatu yang baru, tepat pada waktu dan mempunyai ilmu pengetahuan yang luas. Justeru itu, kajian ini akan mengenal pasti faktor-faktor tarikan dakwah Mohd Fadli Yusof dalam pengislaman masyarakat non-muslim di pedalaman Pensiangan, Sabah.

\section{Suatu Kajian Lapangan terhadap Dakwah Mohd Fadli Yusof}

Kajian ini telah menggunakan kaedah lapangan bagi mendapatkan data mengenai faktor-faktor tarikan dakwah Mohd Fadli Yusof dalam pengislaman masyarakat non-muslim di pedalaman Pensiangan, Sabah. Data lapangan ini telah diperolehi di Kampung Padang, Mukim Sepulut, Pensiangan Sabah. Kampung ini terletak di kawasan pedalaman Pensiangan yang mempunyai jarak lebih kurang 250 kilometer dari Kota Kinabalu, Sabah. Majoriti penduduk Kampung Padang telah diislamkan melalui dakwah Mohd Fadli Yusof dan sebuah masjid telah dibina di Kampung Padang sepanjang dakwah beliau di pedalaman Pensiangan, Sabah. Kampung ini terletak berhampiran dengan Pusat Latihan Mubaligh Kristian di Salarom Taka, Sepulut pedalaman Pensiangan, Sabah.

Dalam kaedah penyelidikan kualitatif, penulis merupakan instrumen utama dalam mendapatkan data di lapangan. Sebagai instrumen, penulis juga terlibat dalam membuat keputusan sebanyak mungkin dalam penglibatannya di lapangan. Segala maklumat yang berbentuk hebahan, perkongsian, catatan

${ }^{19}$ Ab Aziz Mohd Zin, Pengantar Dakwah Islamiah (Kuala Lumpur: Penerbit Universiti Malaya, 1997), 99-103. 
pemerhatian, mendengar, menyoal dan membuat rakaman, mengambil gambar dan merekod bahan-bahan visual di Kampung Padang, Sepulut, Pensiangan. Sebelum melakukan kajian sebenar di lapangan, rappo di antara penulis dan informan adalah penting dalam kajian berbentuk kualitatif sepertimana yang dicadangkan Glesne. ${ }^{20}$ Rappo memudahkan penyelidik mendapatkan maklumat yang secukupnya dan membolehkan responden memberikan pelbagai maklumat personel.

Bagi tujuan tersebut, data lapangan telah diperolehi dengan menggunakan kaedah temu bual bual separa berstruktur. Informan telah dipilih secara bertujuan (purposive) berdasarkan objektif kajian yang telah digariskan. Informan utama ialah Mohd Fadli Yusof dan beberapa informan lain yang di kenal pasti iaitu orang sekeliling beliau dan saudara baru yang diislamkan beliau. Pemilihan informan lain bertujuan untuk mendapatkan data secara keseluruhan mengenai subjek yang di kaji. Bahkan meningkatkan kesahan dan kredibiliti data supaya selari dengan realiti penyelidikan. ${ }^{21}$

Hasil kajian mendapati Mohd Fadli Yusof merupakan seorang pendakwah bebas yang berasal daripada negeri Perak Darul Ridzuan. Beliau telah berjaya mengislamkan 269 orang nonmuslim (jumlah pengislaman sehingga Disember 2013) yang berketurunan suku kaum Murut di bahagian pedalaman Pensiangan sejak tahun 2011. Kebanyakan non-muslimyang telah diislamkan terdiri daripada orang tua, orang dewasa, remaja, wanita dan kanak-kanak; serta mempunyai pelbagai latarbelakang pekerjaan seperti petani, pemburu, ketua kampung, paderi, pengerusi gereja, pelajar dan lain-lain. Dapatan kajian menunjukkan, faktor-faktor tarikan dakwah Mohd Fadli Yusof dalam mengislamkan masyarakat non-muslim di pedalaman Pensiangan, Sabah adalah seperti berikut:

${ }^{20}$ Abdul Sukor Shaari et al., "Kanak-kanak Minoriti Orang Asli di Malaysia: Mengapai Literasi Bahasa Melayu," Jurnal Pendidikan Bahasa Melayu 1 (November 2011), 62.

${ }^{21}$ Othman Lebar, Penyelidikan Kualitatif Pengenalan kepada Teori dan Metod (Tanjung Malim Perak: Penerbit Universiti Pendidikan Sultan Idris, 2009), 185. 


\section{Faktor Tarikan Qudwah}

Tarikan qudwah ialah contoh perbuatan yang menarik perhatian non-muslim di pedalaman Pensiangan untuk mengikuti atau menerima dakwah Mohd Fadli Yusof. Contoh ikutan yang menarik perhatian mereka ialah semasa dalam pergaulan yang bersifat interpersonal. Terdapat dua bentuk pergaulan iaitu pergaulan Mohd Fadli Yusof dengan non-muslim secara peribadi seperti kenalan dan urusan. Menurut beliau, sejak tahun 2012 terdapat beberapa orang non-muslim yang sering mengikutinya setiap kali ziarah ke kampung-kampung di pedalaman Pensiangan, seperti juru pandu perahu, pemandu kenderaan sewa dan lain-lain. Walaupun pergaulan tersebut di atas urusan perkhidmatan, namun pergaulan tersebut telah menarik perhatian non-muslim untuk mengenali beliau lebih rapat. ${ }^{22}$

Seorang informan yang ditemui penulis dikenali Yusof @ Joseph mengakui perkara tersebut. Beliau hanya mengenali Mohd Fadli Yusof pada pertengahan tahun 2012 dan sering mengikutinya di pedalaman Pensiangan. Akhirnya pada bulan September 2013, beliau telah membuat keputusan untuk memeluk Islam setelah tertarik dengan akhlak yang ditunjukkan oleh beliau yang sentiasa bertutur secara lemah lembut dan baik hati. ${ }^{23}$ Manakala seorang informan yang dikenali Ayub @ Jelirus pula menyatakan kepada penulis bahawa beliau juga sudah lama mengenali rapat dan sering mengikuti Mohd Fadli Yusof di Sabah. Sepanjang perkenalan ini, Mohd Fadli Yusof sering menceritakan tentang kebaikan menjadi seorang Islam. Akhirnya pada bulan November 2013, beliau telah membuat keputusan memeluk Islam bersama isteri dalam tempoh perkenalan dengan Mohd Fadli Yusof selama setahun lebih. ${ }^{24}$ Begitu juga dengan pengalaman Mohd Fadli Yusof dalam mengislamkan seorang pemuda pedalaman yang dilihat sangat hampir untuk memeluk Islam kerana sentiasa mengikutinya dan suka bertanya tentang Islam.

22 Mohd Fadli Yusof (Pendakwah Bebas di Sabah), dalam temubual dengan penulis, 14 Januari 2014.

23 Muhammad Yusof@ Joseph (Saudara Baru di Kampung Padang, Mukim Sepulut Pensiangan, Sabah), dalam temubual dengan penulis, 16 Januari 2014.

24 Muhammad Ayyub @ Jelirus (Saudara baru dari Kampung Piowou, Pensiangan, Sabah), dalam temubual dengan penulis, 16 Januari 2014. 
Akhirnya pada bulan ketujuh perkenalan beliau, pemuda ini telah bersedia untukmemeluk Islam. ${ }^{25}$

Selain itu, akhlak yang ditunjukkan oleh Mohd Fadli Yusof dan saudara-saudara baru yang telah diislamkan juga memberikan impak kepada non-muslim lain di Kampung Padang, Sepulut dan kawasan lain di pedalaman Pensiangan.Seorang saudara baru yang dikenali Rimin Ansalin dikatakan tertarik dengan Islam setelah melihat orang Islam menyumbang tenaga secara sukarela dalam pembinaan masjid di Kampung Padang, Sepulut. Ini menyebabkan beliau mahu terlibat sama dengan meminta izin untuk membantu menjaga dan membersihkan tapak pembinaan masjid. Sepanjang tempoh ini, beliau sering memerhatikan sikap rajin yang ditunjukkan Mohd Fadli Yusof bersama-sama dengan saudara baru mendapatkan kayu hutan untuk membina masjid. Akhirnya beliau memeluk Islam selepas beberapa minggu masjid tersebut disiapkan. ${ }^{26}$ Dalam kisah pengislaman seorang non-muslim yang dikenali Joseph Bin Siuh pula, beliau sangat tertarik dengan akhlak yang ditunjukkan Mohd Fadli Yusof dan saudara baru di Kampung Padang, Sepulut yang sentiasa menunjukkan hubungan ukhwah yang kuat, saling membantu dan mengerjakan ibadah walaupun berada di mana sekalipun. Ini menyebabkan beliau tertarik untuk mengikuti dakwah Mohd Fadli Yusof. Akhirnya beliau memeluk Islam secara sukarela bersama isteri dan anakanak di Kampung Padang, Sepulut. ${ }^{27}$

Bentuk pergaulan kedua ialah akhlak yang ditonjolkan oleh saudara baru dengan ahli keluarga, rakan-rakan dan saudara mara mereka yang masih non-muslim. Kebanyakan saudara baru di Kampung Padang, Sepulut dan di kawasan lain di pedalaman Pensiangan, telah memainkan peranan penting sebagai pendakwah kepada ahli keluarga atau rakan-rakan mereka sendiri. Mereka tetap mengekalkan hubungan dengan ahli keluarga, rakan-rakan dan saudara mara yang bukan Islam sepertimana biasa selepas memeluk Islam. Kebiasaannya, setelah seseorang memeluk Islam,

25 Jamuddin Lorrie @ Najmuddin (Ketua Penduduk Kampung Padang Mukim Sepulut, Pensiangan, Sabah), dalam temubual dengan penulis, 16 Januari 2014.

${ }^{26}$ Muhammad Yusof@ Joseph (Saudara Baru di Kampung Padang, Mukim Sepulut Pensiangan, Sabah), dalam temubual dengan penulis, 16 Januari 2014.

27 Muhammad Yusof@ Joseph (Saudara Baru di Kampung Padang, Mukim Sepulut Pensiangan, Sabah), dalam temubual dengan penulis, 16 Januari 2014. 
ia akan dituruti oleh ahli keluarga yang lain untuk menerima Islam. $^{28}$

Di antara faktor yang mendorong ahli keluarga mereka memeluk Islam ialah penghayatan akhlak Islam yang ketara seperti suka membantu, rajin, baik dengan ibu bapa, bersikap lemah lembut dan mempunyai budi pekerti yang baik. ${ }^{29}$ Faktor ini juga mendorong sebahagian ahli keluarga atau saudara mara mereka menerima dakwah Mohd Fadli Yusof di Kampung Padang, Sepulut kerana memberikan kesan positif kepada perubahan diri seseorang selepas memeluk Islam. ${ }^{30}$ Mereka tidak mencurigai keislamannya, bahkan semakin hubungan sesama ahli keluarga sekalipun berbeza agama. Keadaan ini turut mendorong segelintir ibu bapa di pedalaman untuk memberi keizinan anakanak mereka diislamkan oleh Mohd Fadli Yusof. ${ }^{31}$ Seorang informan dikenali Ayub@ Jelirus menyatakan kepada penulis bahawa situasi ini amat berbeza dengan pendirian ibu bapa atau penjaga. Sebelum ini, mereka melihat Islam dengan pandangan negatif. Tetapi sejak kedatangan Mohd Fadli Yusof di pedalaman telah mengubah persepsi segelintir ibu bapa terhadap dakwah Islam berbanding keadaan yang telah dialaminya ketika waktu bersekolah dahulu. ${ }^{32}$

\section{Faktor Tarikan Quwwah}

Tarikan quwwah ialah unsur-unsur kuat yang mempengaruhi nonmuslim terhadap dakwah Mohd Fadli Yusof di pedalaman Pensiangan, Sabah. Faktor tarikan quwwah dapat dilihat kepada dua bentuk. Pertama, tarikan quwwah daripada personaliti Mohd Fadli Yusof sendiri. Beliau dilihat sebagai seorang yang berani dalam menyampaikan agama Islam kepada masyarakat yang asing

28 Mohd Fadli Yusof (Pendakwah Bebas di Sabah), dalam temubual dengan penulis, 14 Januari 2014.

29 Abdullah Ongkil @ Amparing (Saudara baru di Kampung Salong, Sepulut Pensiangan, Sabah), dalam temubual dengan penulis, 16 Januari 2014.

30 Jamuddin Lorrie @ Najmuddin (Ketua Penduduk Kampung Padang Mukim Sepulut, Pensiangan, Sabah), dalam temubual dengan penulis, 16 Januari 2014.

31 Muhammad Fidauddin bin Mohd Fadli (anak ketiga Mohd Fadli Yusof), dalam temubual dengan penulis, 13 Januari 2014.

${ }^{32}$ Muhammad Ayub @ Jelirus (Saudara baru di Kampung Piowou, Pensiangan, Sabah), dalam temubual dengan penulis, 16 Januari 2014. 
dalam kehidupannya. Seorang informan menyatakan kepada penulis, bahawa beliau merupakan seorang yang berani menemui masyarakat di pedalaman secara individu. Beliau dilihat bersusah payah masuk ke kawasan hutan yang mencabar dengan ditemani isteri semata-mata untuk menemui orang di pedalaman Pensiangan. ${ }^{33}$

Amat sukar orang luar yang masuk ke pedalaman Pensiangan untuk menyampaikan dakwah kerana tiada pengangkutan awam, kawasan berbukit-bukit dan masih dipenuhi dengan hutan tebal. Begitu juga dengan keadaan masyarakat yang tidak di pedalaman. Mereka tidak sepertimana masyarakat yang tinggal di pekan dan bandar. Kebanyakan masyarakat yang tinggal pedalaman Pensiangan berasal dari suku kaum Murut. Mereka mempunyai cara kehidupan yang berasaskan suasana sekeliling di hutan. Mereka mengamalkan aktiviti penanaman padi huma, mengamalkan pertanian pindah dan memungut hasil-hasil hutan seperti rotan, damar, sarang burung dan sebagainya. Mereka juga terkenal sebagai pemburu yang handal menggunakan sejenis alat yang dikenali sebagai sumpit dan memiliki anjing perburuan. ${ }^{34}$

Sebelum kedatangan pihak Syarikat Berpiagam Borneo Utara British (BNBCC) di Sabah, suku kaum Murut dikatakan mengamalkan cara hidup yang kuat minum tapai secara berlebihan, suka bersengketa dan amalan pemburuan kepala (head hunting) antara etnik Murut. ${ }^{35}$ Amalan memenggal kepala dikenali sebagai 'antaboh.' Ia dilakukan untuk berjumpa dengan roh datuk moyang yang disebut Aki Kaulung yang telah mati. Dengan amalan ini mereka mempercayai peningkatan kuasa roh dalam diri dan boleh membantunya. ${ }^{36}$

Sifat keberanian Mohd Fadli Yusof yang masuk ke pedalaman Pensiangan untuk menyampaikan dakwah telah

33 Abdul Aziz @ Robert (Saudara Baru di Kampung Padang, Mukim Sepulut Pensiangan, Sabah), dalam temubual dengan penulis, 16 Januari 2014.

${ }^{34}$ Siti Aidah Hj. Lokin, Perubahan Sosioekonomi dan Pentadbiran Masyarakat Peribumi Sabah (1881-1963) (Kota Kinabalu: Penerbit Universiti Malaysia Sabah, 2007), 13.

${ }^{35}$ Tregonning, K.G, Under Chartered Company Rule (North Borneo 1881-1946) (Singapura: Universiti Malaya Press, 1958), 209.

${ }^{36}$ Abdul Hakim Mohad, "Spiritual Journey of Murut Tahol and Its Effect to their Headhunting Practise," International Journal of Science and Humanity 4 (November 2010), 427. 
menimbulkan persoalan masyarakat di situ. Dalam ilmu psikologi, persoalan-persoalan yang timbul dalam diri manusia merupakan suatu bentuk tarikan yang menuntut seseorang mengetahui agar ia menjadi suatu kepuasan. ${ }^{37}$ Bagi tujuan tersebut, kebanyakan mereka yang diziarahi sering bertanyakan tujuan kehadiran yang berulang kali di pedalaman bersama isteri. Beliau menjelaskan tujuan kedatangannya di pedalaman adalah mencari saudara seislam untuk dilihat keadaan mereka, diberi bantuan dan bimbingan. Jawapan ini menyebabkan mereka terdiam dan berfikir sesuatu. Tanpa di duga selang beberapa hari, terdapat beberapa orang yang menelefon beliau dan menyatakan ingin menjadi saudaranya iaitu mahu memeluk Islam, sepertimana dalam petikan temu bual berikut:

"Rupanya, perkataan "saudara" itu amat menarik hati mereka untuk mengenali Islam. Dalam bahasa murut, saudara itu disebut pahaka. Hingga kini semakin ramai yang punya impian menjadi saudara Islam, insyaAllah.,"38

Kedua, dapatan kajian juga menunjukkan pembinaan masjid di Kampung Padang telah menjadi suatu tarikan quwwah dalam pendekatan dakwah Mohd Fadli Yusof. Masjid ini telah dibina pada tahun 2012 dan dinamakan 'Masjid As-Syahadah' sempena pengislaman seorang individu pada hari pertama solat berjamaah didirikan di masjid. ${ }^{39}$ Sebelum itu, kebanyakan saudara baru hanya menggunakan dewan serbaguna untuk tujuan solat dan pengajian. Disebabkan jumlah saudara baru yang semakin meningkat, Mohd Fadli Yusof telah mengambil keputusan untuk membina sebuah masjid di atas tanah yang telah diwakafkan oleh seorang penduduk kampung yang bernama Puan Julia. ${ }^{40}$

Pembinaan masjid ini dapat dilihat sebagai faktor tarikan quwwah yang dianggap luar biasa bagi masyarakat non-muslim di pedalaman. Masjid ini turut dibina dengan kerjasama saudara baru di Kampung Padang dan kampung-kampung yang berhampiran. Mereka telah menunjukkan semangat tinggi untuk menjadikan

\footnotetext{
37 Ab. Aziz Mohd Zin, Psikologi Dakwah (Kuala Lumpur: Jabatan Kemajuan Islam Malaysia (JAKIM), 84.

${ }^{38}$ Mohd Fadli Yusof (Pendakwah Bebas di Sabah), dalam temubual dengan penulis, 14 Januari 2014.

39 Mohd Fadli Yusof (Pendakwah Bebas di Sabah), dalam temubual dengan penulis, 14 Januari 2014.

40 Ibid.
} 
suatu realiti sebuah masjid di kawasan pedalaman. Mereka sanggup bersusah payah mencari balak di hutan, menebang pokok balak dan memotong kayu semata-mata untuk membina masjid. Setelah siap dibina, masjid telah mendapat perhatian non-muslim dan pihak gereja di sekitar kawasan tersebut kerana hampir setiap bulan ada non-muslim yang datang menemui Mohd Fadli Yusof di situ untuk memeluk Islam. Keadaan ini turut membimbangkan pihak missionari di pedalaman kerana berlaku pengislaman dan pembinaan masjid yang seiring. Bahkan perkara seperti ini belum pernah berlaku lagi di pedalaman Pensiangan. ${ }^{41}$

Selain itu, kewujudan masjid ini telah menarik perhatian masyarakat non-muslim di pedalaman mengenali Islam dengan lebih hampir. Sebelum ini mereka tidak terdedah dengan cara kehidupan orang Islam, namun kewujudan masjid ini telah memberi tarikan kuat kepada masyarakat non-muslim pedalaman untuk datang ke Kampung Padang. Penulis telah menemui seorang informan yang dikenali Muhammad Suffian Mohd Sulaiman. Beliau berasal dari Wilayah Persekutuan Labuan dan tinggal bersama-sama penduduk di Kampung Padang, Sepulut sebagai pembimbing secara sukarela. Beliau secara sukarela membantu menguruskan berkaitan dengan hal ehwal penduduk, menghantar anak-anak ke sekolah, mengajar penduduk tentang ibadah, membaca al-Qur'ān dan lain-lain. Beliau menceritakan setiap kali azan berkumandang terdapat beberapa non-muslim di kawasan sekitar ini yang memerhati dari jauh. Ia dilihat seperti sesuatu yang menakjubkan kerana amat jarang azan kedengaran di pedalaman Pensiangan. ${ }^{42}$ Seorang informan menyatakan kepada penulis bahawa masjid di Kampung Padang telah mendorongnya untuk sering menziarahi saudara-saudara baru di situ kerana suka dengan keadaan masjid. Beliau merasa suka dan kagum dengan perubahan cara hidup saudara baru di situ yang dilihat mempunyai cara kehidupan rapat dengan masjid setiap hari. Informan ini memberitahu penulis:

"Dulu masa saya Kristian, saya ada jumpa kawan orang Islam dan tanya mana bangunan orang Islam. Hari ini, saya lihat

${ }^{41}$ Pamail (Saudara Baru, Bekas Pastor Gereja Kristian Basel, Silungai Pagalungan, Sabah), dalam temubual dengan penulis, 15 Januari 2014.

${ }^{42}$ Muhammad Suffian Mohd Sulaiman (Pendakwah di Kampung Padang, Sepulut Pensiangan, Sabah) dalam temubual dengan penulis, 14 Januari 2014. 
masjid di Kg. Padang dan tengok kawan-kawan Islam dan tidak sama apa yang gereja cakap pasal Islam. Akhirnya saya masuk Islam.".

Selain itu, faktor quwwah melalui masjid ini juga boleh dilihat kepada dua aspek iaitu masjid ini merupakan sesuatu perkara yang baru bagi masyarakat di Kampung Padang, Sepulut dan kawasan lain di pedalaman Pensiangan. Sebelum ini mereka tidak pernah melihat secara dekat keadaan masjid dan cara ibadah orang Islam di pedalaman kecuali di pekan Sook dan Keningau. Orang Islam di pedalaman sangat sedikit jumlahnya. ${ }^{44}$ Kedua, masjid ini telah membentuk gambaran menarik dalam aktiviti orang Islam yang meliputi semua peringkat umur kerana sangat jarang dilihat oleh non-muslim di pedalaman sebelum ini. Tambahan pula, kewujudan masjid tersebut telah memberikan impak-impak lain dalam pembangunan infrastruktur dan sosioekonomi masyarakat setempat. Disebabkan penggunaan yang meningkat, pihak berwajib menambah kemudahan-kemudahan lain di kampung ini seperti lampu limpah, pencawang komunikasi, jalan berturap, penambahbaikkan saluran air, jambatan gantung dan lain-lain. Di samping itu, masyarakat kampung tersebut telah dilibatkan dengan aktiviti-aktiviti sosioekonomi secara sistematik berasaskan sumber tempatan. Mohd Fadli Yusof dan sebahagian saudara baru sedang mengusahakan perkhidmatan pengangkutan kenderaan dan perahu sewa, pertanian sawit dan ternakan lembu. ${ }^{45}$ Ia boleh menjadi contoh kepada masyarakat lain di pedalaman Pensiangan gambaran sebagai seorang muslim baik dan mempunyai kemajuan ekonomi yang mantap. ${ }^{46}$

\footnotetext{
43 Muhammad @ Micheal (Saudara Baru di Kampung Padang, Mukim Sepulut Pensiangan, Sabah), dalam temubual dengan penulis, 16 Januari 2014.

44 Jamuddin Lorrie @ Najmuddin (Ketua Penduduk Kampung Padang Mukim Sepulut, Pensiangan, Sabah), dalam temubual dengan penulis, 16 Januari 2014.

45 Mohd Fadli Yusof (Pendakwah Bebas di Sabah), dalam temubual dengan penulis, 14 Januari 2014.

46 Jamuddin Lorrie @ Najmuddin (Ketua Penduduk Kampung Padang Mukim Sepulut, Pensiangan, Sabah), dalam temubual dengan penulis, 16 Januari 2014.
} 


\section{Faktor Tarikan Kelainan}

Tarikan kelainan ialah sesuatu perkara yang berbeza dengan kelaziman, pelik atau bersifat luar biasa. ${ }^{47}$ Faktor tarikan kelainan dalam dakwah Mohd Fadli Yusof boleh dilihat kepada tiga aspek. Pertama, kehadiran Mohd Fadli Yusof di kawasan penempatan suku kaum Murut dengan mengunjungi setiap rumah selama beberapa bulan di pedalaman Pensiangan. Ia dianggap sebagai suatu kelainan kerana jarang orang luar masuk ke pedalaman semata-mata untuk menemui mereka di situ kerana penempatannya jauh dari kemudahan. Kecuali wakil-wakil kerajaan yang bertugas di pedalaman seperti guru dan pegawai kerajaan untuk tugas rasmi. Namun cara dakwah Mohd Fadli Yusof yang masuk ke pedalaman Pensiangan telah menggambarkan suatu kelainan dan jarang berlaku bagi masyarakat setempat. Apatah lagi beliau berasal daripada semenanjung. ${ }^{48}$

Kedua, pendekatan dakwah Mohd Fadli Yusof yang membawa bersama isteri dan anak-anak di pedalaman Pensiangan. Kehadiran mereka sekeluarga di kawasan pedalaman dianggap sebagai suatu kelainan dari kebiasaan orang luar yang masuk. Namun dari sudut pandangan masyarakat, ia menggambarkan suatu keadaan yang menarik perhatian dan menyentuh perasaan kerana beliau sentiasa bersama isteri dan anak-anak, sepertimana petikan temu bual berikut:

"Dia masuk (pedalaman) dengan isteri dan anak-anak. Kami terharu dan mahu membantunya kerana dia orang luar yang datang ke rumah kami berjalan kaki, naik perahu. Tapi dia memang mahu jumpa kami. Lama-lama kami rasa gembira dia di sini.", 49

Ini menunjukkan kedatangan Mohd Fadli Yusof bersama dengan ahli keluarganya telah menyentuh hati penduduk di pedalaman. Dalam mengetahui perkara ini lebih detail, Mohd Fadli Yusof menjelaskan kepada penulis bahawa tujuan membawa

${ }^{47}$ Ab Aziz Mohd Zin, Psikologi Dakwah (Kuala Lumpur: Jabatan Kemajuan Islam Malaysia (JAKIM), 56-58.

48 Muhammad Yusof@ Joseph (Saudara Baru di Kampung Padang, Mukim Sepulut Pensiangan, Sabah), dalam temubual dengan penulis, 16 Januari 2014.

49 Muhammad Jordan (Saudara Baru di Kampung Padang, Mukim Sepulut Pensiangan, Sabah), dalam temubual dengan penulis, 16 Januari 2014. 
isteri dan anak bukan untuk menarik perhatian orang lain. Bahkan kebersamaan keluarga semasa di lapangan dakwah sangat penting pada masa kini. Ia dilakukan bagi menggelakkan fitnah yang boleh membantutkan kerja dakwah. Jarang sekali pendakwah membawa bersama isteri dan anak-anak. Beliau mengakui isteri dan anakanak lelakinya berperanan sebagai pembantu dalam gerak kerja dakwah di pedalaman Sabah. ${ }^{50}$ Isteri membantu dalam mendekati golongan wanita dan anak-anaknya pula berperanan mendekati golongan remaja dan anak-anak. ${ }^{51}$ Di sebalik itu, ia dapat menjalinkan ikatan atau perasaan kasih sayang secara tidak langsung, sekalipun mereka bukan seagama dan sebangsa. Bahkan kebanyakan informan yang ditemui penulis mengakui mereka merasa selesa dan seronok dapat bertemu beliau sekeluarga tanpa rasa curiga. ${ }^{52}$

Mereka dapat memainkan peranan dalam pertemuan dengan non-muslim melalui sentuhan fizikal dan emosi seperti berjabat tangan atau bersalaman, berpelukan dan mengusap. Sentuhan seperti ini dapat menguatkan hubungan yang di bina dan menjauhkan dari sangkaan negatif.Ia turut disarankan Nabi SAW sebagaimana hadith yang diriwayatkan al-Khurāsānī:

$$
\begin{aligned}
& \text { عن عطاء بن أبي مسلم عبدالله الخراساني قال: قال }
\end{aligned}
$$

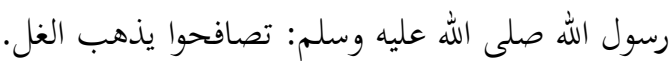

Terjemahan: Daripada 'Ațā' bin Abī Muslim 'Abdillah alKhurāsān̄̄, berkata: Nabi SAW telah bersabda: "Berjabat tanganlah (nescaya akan hilang) pergi kedengkian dalam hati.",53

Ketiga, cara pakaian Mohd Fadli Yusof dilihat berbeza dengan masyarakat tempatan. Beliau bersama ahli keluarga sentiasa mengenakan pakaian berjubah dan berserban. Penampilan

50 Mohd Fadli Yusof (Pendakwah Bebas di Sabah), dalam temubual dengan penulis, 14 Januari 2014.

${ }^{51}$ Siti Aisyah Nordin (Isteri Mohd Fadli Yusof), dalam temubual dengan penulis, 14 Januari 2014.

52 Jamuddin Lorrie @ Najmuddin (Ketua Penduduk Kampung Padang Mukim Sepulut, Pensiangan, Sabah), dalam temubual dengan penulis, 16 Januari 2014.

${ }^{53}$ Hadith riwayat Imam Malik dalam kitab al-Muwatțā.' Kitāb al-Jāmi’, Bab Mā Jā'a fì al-Muhājirah, no. hadith 16. Lihat Muhammad Fuad 'Abd al-Bāqī, "Muwatțā' Imam Mālik” (Beirut: Dār Ihyā' al-Turāth al-'Arabī, 1985), 908. 
dengan berserban dan berjubah mungkin dianggap pelik dalam pandangan masyarakat setempat. Tetapi yang pelik itulah yang mendapat perhatian. Dengan barakah sunnah Rasulullah SAW, mereka telah menerima hidayah, memeluk dan mengamalkan Islam. $^{54}$ Beliau sering berpakaian Melayu yang berwarna cerah, sekalipun berwarna hitam. Ia seolah-olah menggambarkan seperti pakaian masyarakat Melayu Islam di Malaysia menyambut hari raya Aidilfitri. Ia seolah-olah menonjolkan suasana kegembiraan. Cara pakaian seperti ini amat jarang digunakan, apatah lagi di dalam masyarakat pedalaman Pensiangan. Penampilan tersebut telah menarik perhatian non-muslim terhadap dakwah beliau di Kampung Padang, Sepulut dan kawasan lain di pedalaman Pensiangan, Sabah.

\section{Faktor Tarikan Berulang-ulang}

Berulang-ulang ialah melakukan sesuatu perkara berulang kali untuk membentuk suatu pengukuhan yang boleh mempengaruhi orang lain. ${ }^{55}$ Tarikan berulang-ulang dalam dakwah Mohd Fadli Yusof dapat dilihat pendekatan ziarah yang dilakukan, memberi hadiah dan menjemput makan kenduri. Beliau sentiasa memberikan hadiah kepada non-muslim setiap kali melakukan ziarah, sekalipun dalam ziarah susulan. Tujuannya adalah untuk mengukuhkan hubungan di atas ziarah yang dilakukan. Seorang informan yang sering mengikuti beliau menyatakan kepada penulis bahawa sebelum masuk ke Kampung Padang, Sepulut, mereka akan mencari barangan keperluan di pekan Keningau untuk diberikan kepada penduduk semasa ziarah. Beliau akan memastikan sumbangan mesti disampaikan setiap kali ziarah ke rumah penduduk. ${ }^{56}$ Keadaan ini telah menarik perhatian nonmuslim kerana mereka sentiasa mendapat buah tangan dalam setiap ziarah.

Seorang informan menyatakan kepada penulis, bahawa mereka sangat terharu dengan kunjungan dan sumbangan Mohd

54 Mohd Fadli Yusof (Pendakwah Bebas di Sabah), dalam temubual dengan penulis, 14 Januari 2014.

55 Ab Aziz Mohd Zin, Psikologi Dakwah (Kuala Lumpur: Jabatan Kemajuan Islam Malaysia (JAKIM), 56-58.

${ }^{56}$ Abang Abdul Rahman bin Taip (Pelajar Universiti Teknologi Petronas (UTP), dalam temubual dengan penulis, 15 Januari 2014. 
Fadli Yusof yang berulang kali. Mereka juga dapat mengenali hati budi beliau sebagai seorang Islam yang baik. ${ }^{57}$ Mereka kagum dengan tindakan Mohd Fadli Yusof dan isteri yang bersusah payah memberikan sumbangan dan melihat keadaan hidup mereka di kawasan hutan. Ini menunjukkan Mohd Fadli Yusof telah berjaya membina hubungan baik dengan non-muslim melalui ziarah dan memberi sumbangan secara berulang-ulang. Keadaan ini telah memberikan kesan positif dalam pendekatan dakwah beliau di Kampung Padang, Sepulut dan kawasan lain di pedalaman Pensiangan. Sepertimana dinyatakan Ab Aziz Mohd Zin, sikap gembira yang ditunjukkan non-muslim semasa menerima ziarah orang luar dapat memudahkan mesej dakwah disampaikan dengan berkesan. ${ }^{58}$ Ia dianggap sebagai suatu bentuk pengukuhan dalam membina atau mengekalkan hubungan baik dengan non-muslim dan membina persepsi positif serta dapat menggelakkan sifat curiga.

\section{Faktor Tarikan Keprihatinan}

Tarikan keprihatinan ialah kesungguhan dalam mengambil berat tentang sesuatu perkara. ${ }^{59}$ Mohd Fadli Yusof dilihat sentiasa mengambil tahu dan mendengar masalah-masalah yang dihadapi penduduk sama ada berkaitan dengan hal keluarga dan masyarakat. Antara perkara yang sentiasa di ambil berat oleh beliau ialah berkaitan dengan keluarga dan pendidikan anakanak. $^{60}$ Sekiranya terdapat keluarga yang memerlukan bantuan rawatan atau kewangan, beliau akan cuba membantu dengan cara semampu yang mungkin. ${ }^{61}$ Jika terdapat di kalangan mereka yang sakit, beliau cuba merawatnya sendiri atau memberi kemudahan kepada pesakit untuk di hantar ke hospital. Beliau pernah

57 Muhammad Yusof@ Joseph (Saudara Baru di Kampung Padang, Mukim Sepulut Pensiangan, Sabah), dalam temubual dengan penulis, 16 Januari 2014.

58 Ab. Aziz b. Mohd. Zin, "Sasaran Dakwah Non-Muslim di Malaysia: Suatu Kajian Tentang Keadaan Orang Asli di Perkampungan Orang Asli Ulu Kuang, Gombak Selangor," Jurnal Usuluddin 2 (1995): 38.

59 Ab Aziz Mohd Zin, Psikologi Dakwah (Kuala Lumpur: Jabatan Kemajuan Islam Malaysia (JAKIM), 56-58.

${ }^{60}$ Muhammad Yusuf @ Joseph (Saudara Baru di Kampung Padang, Mukim Sepulut Pensiangan, Sabah), dalam temubual dengan penulis, 16 Januari 2014.

61 Oboy @ Ambaan (Saudara Baru di Kampung Padang, Mukim Sepulut Pensiangan, Sabah), dalam temubual dengan penulis, 16 Januari 2014. 
membantu pesakit non-muslim yang terkena bisa ular semasa memburu, ${ }^{62}$ merawat penduduk yang terkena sihir dan sebagainya. Beliau juga banyak membantu penduduk mendapatkan rawatan di hospital sekalipun terpaksa dihantar ke Kota Kinabalu yang mempunyai jarak hampir 250 kilometer dari Kampung Padang. ${ }^{63}$

Selain itu, Mohd Fadli Yusof pernah membantu seorang paderi Kristian yang menghadapi musibah di atas kematian ahli keluarganya. Beliau tidak mengenalinya, namun pernah mengetahui tentang paderi itu melalui ziarah yang dilakukan sebelum ini. Di atas sifat kemanusiaan, beliau telah memberikan sumbangan wang untuk meringankan beban yang dihadapi walau berada semenanjung dengan cara apa sekalipun. Beliau telah mengirimkan wang melalui wakilnya di Kampung Padang, Sepulut. Paderi tersebut merasa terkejut dan terharu di atas sumbangan. ${ }^{64}$ Mohd Fadli Yusof juga sentiasa mengambil berat tentang keadaan di Kampung Padang, Sepulut. Beliau dilihat tidak kekok dengan melakukan kerja-kerja secara sukarela seperti membersihkan kawasan awam, menebas rumput, mengangkat kayu, membaik pulih jambatan gantung, membaik pulih saluran, dan membaik pulih rumah penduduk yang usang bersama-sama saudara baru. ${ }^{65}$

Selain itu, Mohd Fadli Yusof telah mengambil beberapa orang anak angkat sebagai usaha membantu meningkatkan tahap pendidikan mereka. Ia dilakukan di atas nama jagaan atau pusat jagaan, kerana dikhuatiri menimbulkan masalah dari sudut undang-undang. Di dalam perkara 12 fasal [4] Perlembagaan Malaysia menyebutkan bahawa agama bagi seseorang yang berumur kurang daripada lapan belas tahun adalah ditetapkan oleh ibu bapa atau penjaganya. ${ }^{66} \mathrm{Di}$ atas faktor ini, beliau telah membina sebuah asrama yang menempatkan hampir 40 orang

${ }^{62}$ Muhammad Fidauddin Mohd Fadli (Pendakwah Bebas di Sabah), dalam temubual dengan penulis, 15 Januari 2014.

63 Muhammad Ayub @ Jelirus (Penduduk Kampung Piowou, Pensiangan, Sabah), dalam temubual dengan penulis, 16 Januari 2014.

${ }^{64}$ Jamuddin Lorrie @ Najmuddin (Ketua Penduduk Kampung Padang, Mukim Sepulut Pensiangan, Sabah) dalam temubual dengan penulis, 16 Januari 2014.

65 Jamuddin Lorrie @ Najmuddin (Ketua Penduduk Kampung Padang, Mukim Sepulut Pensiangan, Sabah) dalam temubual dengan penulis, 16 Januari 2014.

${ }^{66}$ Perlembagaan Pesekutuan, 2005, (Perkara 12, fasal 4). 
anak-anak yang telah memeluk Islam. ${ }^{67}$ Namun kebanyakan ibu bapa mereka masih belum memeluk Islam dan memberi izin kepada anak-anak mereka untuk memeluk Islam dan memberi kepercayaan kepada beliau untuk menjaga serta memberi pendidikan tentang Islam. ${ }^{68}$ Mereka tidak khuatir dengan serahan jagaan ini di bawah tanggungjawab Mohd Fadli Yusof. ${ }^{69}$

\section{Penutup}

Berdasarkan perbincangan di atas, dapat dinyatakan faktor tarikan dakwah ialah unsur-unsur yang menarik perhatian golongan sasaran kepada dakwah. Hasil kajian menunjukkan terdapat lima faktor tarikan dalam dakwah Mohd Fadli Yusof di pedalaman Pensiangan, Sabah. Pertama, faktor tarikan qudwah yang dilihat melalui akhlak dalam pergaulan Mohd Fadli Yusof dan saudara baru dengan non-muslim. Ia bertepatan dengan teori sejarah penyebaran Islam di Nusantara yang mengaitkan pergaulan di antara muslim dan non-muslim dapat memberikan kesan positif dalam pengislaman masyarakat. Kedua, faktor tarikan quwwah dilihat dengan keberanian Mohd Fadli Yusof masuk ke pedalaman hutan untuk menyampaikan dakwah; dan pembinaan masjid hasil dakwah dilakukan di Kampung Padang, Sepulut Pensiangan, Sabah. Kewujudan masjid tersebut telah menarik perhatian nonmuslim di pedalaman untuk mengenali Islam melalui dakwah Mohd Fadli Yusof. Ketiga, faktor tarikan kelainan yang dilihat tujuan kedatangan Mohd Fadli Yusof dan keluarga di pedalaman Pensiangan merupakan perkara janggal dan beliau mengenakan pakaian berbeza dengan masyarakat tempatan yang dilihat sebagai salah satu tarikan. Keempat, faktor tarikan berulang-ulang yang dilihat melalui pendekatan ziarah, memberi hadiah dan menjemput non-muslim makan kenduri. Kelima, faktor tarikan keprihatinan yang melalui sikap mengambil berat dan menyelesaikan masalah atau bebanan yang dihadapi oleh non-muslim di Kampung Padang, Sepulut dan kawasan lain di pedalaman Pensiangan. Kelima-lima faktor tersebut bersifat da'wah bi al-hāal yang

${ }^{67}$ Mohd Fadli Yusof (Pendakwah Bebas di Sabah), dalam temubual dengan penulis, 14 Januari 2014.

68 Ibid.

69 Muhammad Fidauddin Mohd Fadli (Anak ketiga Mohd Fadli Yusof), dalam temubual dengan penulis, 15 Januari 2014. 
menggambarkan suatu tarikan yang positif dalam menyampaikan dakwah kepada non-muslim.

\section{Bibliografi}

Ab Aziz Mohd Zin. Psikologi Dakwah. Kuala Lumpur: Jabatan Kemajuan Islam Malaysia (JAKIM), 1999.

Penerbit Universiti Malaya, 1997. . Pengantar Dakwah Islamiah. Kuala Lumpur: . "Sasaran Dakwah Non-Muslim di Malaysia:

Suatu Kajian Tentang Keadaan Orang Asli di Perkampungan Orang Asli Ulu Kuang, Gombak Selangor," Jurnal Usuluddin 2 (1995): 38.

Abdul Hakim Mohad. "Spiritual Journey of Murut Tahol and Its Effect to their Headhunting Practise," International Journal of Science and Humanity 4 (November 2010): 427.

Abdul Sukor Shaari et al. "Kanak-kanak Minoriti Orang Asli di Malaysia: Mengapai Literasi Bahasa Melayu." Jurnal Pendidikan Bahasa Melayu 1 (November 2011): 62.

Al-Sha'rāwī, Muhạmmad Mutawallī. Mukhtașar Tafsīr alSha 'rāwī. Kāherah: Dār al-Tawfiqiyyah wa al-Turath, 2011.

H.M. Ariffin. Psikologi Da'wah, Suatu Pengantar Studi. Jakarta: Penerbit Bulan Bintang, 1977.

Jarishah,'Alī. Manāhij al-Da'wah wa Asālibihā. Mansurah: Dār al-Wafā' li al-Țibā'ah wa al-Nashr wa al-Tawzi', 1986.

Cambridge Dictionaries Online, dicapai 25 Jun 2014. http:// dicitionary.cambridge.org/dictionary/ british/ attraction.

Desmond Davidson. "Sabah Christians Meet Today in Bid to Reverse Conversions to Islam." The Malaysian Insider, retrieved on 4 Febuary 2014, http://www.themalaysianinsider. $\mathrm{com} / \mathrm{malaysia/article/sabah-christians-meet-today-in-bid-to-}$ reverse-conversions-to-islam

Ghalūsh, Ahmad Ahmad. Al-Da'wah al-Islāmiyyah Ușūlihā wa Wasā'iluhā. Kaherah: Dār al-Kitab al-Mișr, 1978.

Hornby,A. S. Oxford Advanced Learner's Dictionary. United Kingdom: Oxford University Press, 2011.

Ibrahim Che Noh. "Dakwah kepada Non-Muslim," dalam Dakwah Islamiah Malaysia Masa Kini, ed., Sidi Gazalba dan Zainab Ismail. Bangi: Penerbit Universiti Kebangsaan Malaysia, 1995. 
Kamus Dewan Edisi Keempat. Kuala Lumpur: Dewan Bahasa Dan Pustaka, 2007.

Mahmood Nazar Mohamed. Pengantar Psikologi, Satu Pengenalan Asas Kepada Jiwa dan Tingkahlaku Manusia. Kuala Lumpur: Dewan Bahasa Dan Pustaka, 2005.

Merriam-Webster Online, "An Encyclopedia Britannica Company," dicapai 25 Jun 2014, http://www.merriamwebster. com/dictionary/attraction.

Mohd Yusof Hussain. "Method in Contemporary Islamic Da 'wah," dalam Readings in Islamic Da 'wah, ed. Mohd. Yusof Hussain. Kuala Lumpur: International Islamic University Malaysia (IIUM) Press, 2009.

Morgan, King \& Robinson. Introduction to Psychology. New York: Mc Graw Hill Book Company, 1979.

Muḥammad Fuad 'Abd al-Bāqī. Muwțta' Imam Mālik. Beirut: Dār Ihyā' al-Turāth al-'Arabī, 1985.

Othman Lebar. Penyelidikan Kualitatif Pengenalan kepada Teori dan Metod. Tanjung Malim Perak: Penerbit Universiti Pendidikan Sultan Idris, 2009.

Perlembagaan Persekutuan. Selangor: International Law Book Centre (ILBS), 2005.

Siti Aidah Hj. Lokin. Perubahan Sosioekonomi dan Pentadbiran Masyarakat Peribumi Sabah (1881-1963). Kota Kinabalu: Penerbit Universiti Malaysia Sabah, 2007.

Tregonning, K.G. Under Chartered Company Rule (North Borneo 1881-1946). Singapura: Universiti Malaya Press, 1958.

Zaydān, 'Abd al-Karīm. Ușūl al-Da'wah. Beirut: al-Risālah Publisher, 1998. 
Hadi dan Fakhrul, Faktor Tarikan Dakwah Mohd Fadli Yusof 